\title{
A cluster RCT and process evaluation evaluating the effectiveness of an optimisation intervention to promote parental engagement in a childhood obesity prevention programme: Results of the Optimising Family Engagement in HENRY (OFTEN) trial
}

Maria Bryant (D maria.bryant@york.ac.uk)

University of Leeds https://orcid.org/0000-0001-7690-4098

Wendy Burton

University of York Department of Health Sciences

Michelle Collinson

University of Leeds Faculty of Medicine and Health

Amanda Farrin

University of Leeds Faculty of Medicine and Health

Jane Nixon

University of Leeds Faculty of Medicine and Health

June Stevens

University of North Carolina at Chapel Hill Gillings School of Global Public Health

Kim Roberts

HENRY org

Robbie Foy

University of Leeds Faculty of Medicine and Health

Harry Rutter

University of Bath

Bethan Copsey

University of Leeds Faculty of Medicine and Health

Suzanne Hartley

University of Leeds Faculty of Medicine and Health

Sandy Tubeuf

Université catholique de Louvain: Universite Catholique de Louvain

Julia Brown

University of Leeds Faculty of Medicine and Health 
Research

Keywords: Community, parent, engagement, enrolment, attendance, obesity

Posted Date: April 27th, 2021

DOl: https://doi.org/10.21203/rs.3.rs-188964/v1

License: (c) (i) This work is licensed under a Creative Commons Attribution 4.0 International License. Read Full License 


\section{Abstract}

Background Low parental participation reduces the impact and sustainability of public health childhood obesity prevention programmes. Using data from a focused ethnography, we developed a multi-level, theory-based implementation optimisation intervention. The optimisation intervention aimed to support local authorities and children's centres to adopt behaviours to promote engagement in 'HENRY (Health Exercise Nutrition for the Really Young)', a UK community obesity prevention intervention.

Methods We evaluated the effectiveness of the optimisation intervention on programme enrolment and completion over a 12 implementation period in a cluster randomised controlled trial. We randomised 20 local government authorities (with 126 children's centres) to HENRY plus the optimisation intervention or to HENRY alone. Primary outcomes were (1) the proportion of centres enrolling at least eight parents per programme and (2) the proportion of centres with a minimum of $75 \%$ of parents attending at least five of eight sessions per programme. Trial analyses adjusted for stratification factors (pre-randomisation implementation of HENRY, local authority size, deprivation) and allowed for cluster design. A parallel mixed-methods process evaluation used qualitative interview data and routine monitoring to explain trial results.

Results Neither primary outcome differed significantly between groups; $17.8 \%$ of intervention centres and $18.0 \%$ of control centres achieved the parent enrolment target (adjusted difference $-1.2 \%$; $95 \% \mathrm{Cl}$ : $-19.5 \%$, $17.1 \%) ; 17.1 \%$ of intervention centres and $13.9 \%$ of control centres achieved the attendance target (adjusted difference $1.2 \%$; $95 \% \mathrm{Cl}:-15.7 \%, 18.1 \%$ ). Unexpectedly, the trial coincided with substantial national service restructuring, including centre closures and reduced funds. Some commissioning and management teams stopped or reduced implementation of both HENRY and the optimisation intervention due to competing demands. Thus, at follow up, HENRY programmes were delivered to approximately half the number of parents compared to baseline ( $n=433$ vs. 881 ).

Conclusions During a period in which services were reduced by policies outside the realm of this research, this first definitive trial found no evidence of effectiveness for an implementation optimisation intervention promoting parent engagement in an obesity prevention intervention.

Trial registration: ClinicalTrials.gov Identifier: NCT02675699 registered $4^{\text {th }}$ February 2016. https://clinicaltrials.gov/ct2/show/NCT02675699

\section{Introduction}

The design and delivery of public health interventions to prevent or treat obesity is costly and timeconsuming, and evaluations often report a lack of effect (1-4). Factors that often compromise programmes for childhood obesity are low parental enrolment and attendance at group-delivered programmes, which substantially undermine group dynamics and contribute to reduced effectiveness and cost-effectiveness (5-7). This lack of parental involvement threatens the viability of such programmes. 
The effectiveness of interventions in real-world conditions may not match the efficacy found in research studies (8). Parents may not be motivated to attend prevention programmes because their children show no clinical symptoms $(9,10)$. There is a need for tailored methods to maximise parent participation and enhance implementation in childhood obesity prevention programmes.

Poor parental engagement occurs in the context of health inequalities and, in some cases, safeguarding challenges $(9,11,12)$. Low levels of engagement with services, such as missed clinical appointments, is associated with a range of socioeconomic and cultural factors and may indicate vulnerability particularly in single parent families, those with social or financial deprivation or families from ethnic minority groups (13). This is particularly pertinent given that children from lower socio-economic and ethnic minority groups have the highest prevalence of obesity (14). In addition to the potential public health benefits, low attendance rates in group programmes leads to high intervention costs per family (15).

We developed and evaluated an optimisation intervention to promote parental enrolment and attendance in an existing preschool obesity prevention group programme, HENRY. HENRY is an eight-week groupdelivered programme provided to parents of preschool children. It was developed in 2006 with joint funds from the United Kingdom Department of Health and the former Department of Children, Schools and Families (now the Department for Education) and, at the time of local authority recruitment, was commissioned and delivered nationally by 32 local authorities providing more than 150 programmes each year. It is delivered in community settings, often by staff in children's centres (16). HENRY uses a responsive approach to provide practical guidance and improve parenting skills aimed at enhancing family lifestyle and children's centre environments. Despite some indications of the success of HENRY from audit (16) and qualitative data (17-19), routine monitoring evaluation indicates implementation targets were often not met. Children's centres rarely recruit the target of eight parents per programme (average is six) and only $60 \%$ of parents attend at least five out of eight sessions.

Using data from a focused ethnography study of children's centres where HENRY was delivered (20), we developed a multi-level optimisation intervention promoting parental engagement to the eight week obesity prevention programme HENRY (21). The optimisation intervention was developed over 6 months (July-December 2015) by a multi-disciplinary team, incorporating evidence on effective methods for engagement and data collected iteratively from the ethnography study within five children's centres delivering HENRY programmes (22). The full intervention development process is reported elsewhere (21). Here, we report the results of the Optimising Family Engagement in HENRY (OFTEN) trial, which aimed to determine the effectiveness of this optimisation intervention. Given the complexities of evaluating an intervention within this setting, at a time of national change within local authorities and children's centre funding, we also undertook a comprehensive process evaluation to help understand the influence of such contextual factors on trial findings. This paper reports both the trial findings and a summary of process evaluation findings.

\section{Methods}


The study methods have been reported previously (23) and are summarised below.

\section{Study Design and Participants}

We conducted a two-arm, multi-centre, cluster randomised controlled trial (cRCT) across 20 local authorities in the UK to determine the effectiveness of an optimisation intervention to promote parent engagement in the HENRY programme compared with HENRY alone (standard HENRY practice) (Figure 1). Although children's centres deliver the HENRY programme, due to the multi-component and interacting nature of the optimisation intervention, local authorities were chosen as the unit of randomisation (i.e. clusters) to reduce the likelihood of contamination between the randomised groups. The School of Medicine Research Committee at the University of Leeds (MREC15-017) granted ethical approval for the study.

We recruited local authorities and children's centres within them to the trial. Outcomes were obtained from routine data on engagement (recruitment, attendance and proxy for behaviour change); thus, individual level participant (i.e. parents) recruitment was not sought. In order for local authorities to meet inclusion criteria, they had to already be commissioning HENRY and consent for their centres to be involved in the research. Additionally, HENRY programmes had to be delivered by certified staff. Local authorities planning to decommission the HENRY intervention during the trial period were not eligible. Children's centres were eligible if they provided data for the most recent HENRY programme delivered. Centres which participated in ethnographic work to develop the optimisation intervention and those not planning to deliver any HENRY programmes during the trial period were excluded.

\section{Randomisation and masking}

Local authorities were randomised in a 1:1 allocation ratio (HENRY + optimisation intervention; HENRY alone) by a statistician at the Clinical Trials Research Unit (CTRU). An algorithm for covariateconstrained randomisation was used (24) to achieve a balanced allocation between the trial arms on according to the following pre-randomisation factors: local authority level of parental engagement with HENRY (proportion of centres enrolling a minimum of eight parents per programme; proportion of centres retaining at least $75 \%$ of parents for a minimum of five out of eight sessions); proportion of centres delivering at least one HENRY programme in 2016; size of local authority (number of children's centres participating with more or less than the median number of centres per local authority); and area deprivation (proportion of centres in the least and most deprived quintiles as ranked by the 2015 Index of Multiple Deprivation at the Lower Layer Super Output Area) (25).

Details of the optimisation were limited to a restricted number of central HENRY staff to avoid contamination (management team and named staff responsible for optimisation training). The central HENRY staff who were responsible for collating and transferring data to the CTRU were blinded to treatment allocation. Due to the nature of the intervention, it was not possible to blind allocation within intervention sites. Families attending the HENRY programme are routinely informed at enrolment that 
HENRY uses data anonymously for research (website and privacy notice) but were not explicitly informed about the OFTEN trial or whether their local authority was assigned to the optimisation intervention.

\section{Procedures}

Local authorities and their centres across the UK were identified through an existing database of HENRY delivery sites and invited to take part by direct invitation (posted or emailed by HENRY central office). An opt-out approach was used to promote efficiency and was approved due to the low risk nature of the trial and low centre burden as outcomes were collected using routine data. Centres could decline participation in the study even if they were based within a consenting local authority. However, centres within areas where the local authority declined to take part in the trial were not eligible to participate. At the time of recruitment, 32 local authorities (317 children's centres) in the UK ran the programme.

\section{HENRY alone}

Local authorities randomised to the HENRY alone arm continued to deliver HENRY programmes as per standard practice. HENRY is an eight-week programme delivered in children's centres and aims to provide parents with skills, knowledge and confidence to support healthy behaviours among their preschool children. Approximately 41 local authorities have trained health and community practitioners in the HENRY approach since 2006 across the UK [26]. Stage 1 training is designed to equip centre staff with the knowledge and skills to promote and provide healthy nutrition within early years settings and support parents to provide healthy family lifestyles and nutrition for their families. The theoretical underpinning combines evidenced-based models of behaviour change, including the Family Partnership Model, motivational interviewing and solution-focused support. Stage 2 training supports practitioners to deliver the eight-week HENRY programme to families. This stage aims to build parents' skills, knowledge and confidence to change old habits, provide healthier nutrition for their young children, and encourage healthier lifestyles $(26,27)$. Programme content includes sessions on lifestyle and eating habits (e.g., family meals), balancing healthy meals and snacks, child-appropriate portion sizes, parenting, physical activity and emotional well-being.

\section{Optimisation intervention development (HENRY plus optimisation)}

The HENRY plus optimisation arm delivered HENRY as standard, in addition to the optimisation intervention (20). The Behaviour Change Wheel (BCW) framework (28) guided the development of the intervention which aimed to support local authorities and children's centres to promote parent engagement by encouraging them to adopt recommended engagement strategies (Table 1). The intervention used a multi-level approach to change behaviours at multiple organisational levels within the children's centre context. Intervention components and materials were designed by the HENRY central team who have expertise in intervention design and delivery. A trainer from the central HENRY team provided optimisation intervention training to local authority HENRY coordinators (responsible for coordinating HENRY activities within their area) who implemented the intervention locally. HENRY coordinators typically have a background in health/public health intervention delivery. 
Table 2 summarises the components of the optimisation intervention in line with guidance for intervention description reporting (29). These are aimed at changing the behaviours of local authority commissioners, children's centre managers, children's centre staff, HENRY facilitators, and previous participants of HENRY.

\section{Outcomes}

All local authorities which commission and deliver HENRY routinely provide process data to the central HENRY office for monitoring and quality assurance. Except for qualitative data collected for the process evaluation, this trial only used these routine HENRY data.

Anonymised data that were transferred to the CTRU included: Recruitment and attendance data for programmes run pre-randomisation (baseline) and follow-up (programmes run for a 12 month period after training (6 months)); optimisation intervention training attendance and implementation data (e.g. dates, certification, numbers); and anonymised parent level data (child gender, age, ethnicity, the number and age of children under five in the home and questionnaire data (below)). As families usually only attend one HENRY programme, demographic characteristics differ at each time point.

\section{Primary}

The multiple primary outcomes were: i) the proportion of centres enrolling at least eight parents per programme and ii) the proportion of centres with at least $75 \%$ of parents attending a minimum of five out of eight sessions per programme. The optimisation intervention was to be considered to be effective if either the enrolment or retention goals were met.

\section{Secondary}

The pre-specified secondary outcomes were:

1. Parental adherence as measured via the proxy measure: proportion of parents reporting an increase of 0.5 in the daily frequency of consumption of fruits and vegetables by children per programme as measured by the modified and reduced Food Frequency questionnaire (30).

2. Proportion of children's centres achieving all targets for enrolment, attendance and parent compliance.

3. Assessment of parenting self-efficacy as measured by a modified Parenting Self-Agency questionnaire prior to staring HENRY (pre-programme) and eight weeks later upon completion of the programme (post-programme) $(30,31)$.

4. Assessment of family eating behaviours as measured by a modified Golan Family Eating and Activity Habits questionnaire (pre and post-programme) $(30,32)$.

5. Assessment of family activity as measured by a bespoke HENRY questionnaire (pre and postprogramme). 
6. Assessment of child screen time as measured by a bespoke HENRY questionnaire (pre and postprogramme).

7. Assessment of intake of key indicator foods as measured by a modified Food Frequency questionnaire (pre and post-programme) (30).

8. Longitudinal impact on enrolment and attrition assessed in children's centres which provide data from more than one programme.

\section{Sample size}

Power calculations for a fixed sample size were conducted to examine the anticipated power for various intervention effects, in each of the primary outcomes and adjusting for multiplicity (see Additional Table 1 for scenarios). We assumed $25 \%$ of the 32 local authorities delivering HENRY would be ineligible or would opt out of the trial, leaving 24 local authorities (12 per arm). Based on data from previous HENRY programmes (2014), we assumed an average of 6 children's centres per local authority, providing a total of 144 children's centres (72 per arm), an intra-cluster correlation coefficient (ICC) between 0.05 and 0.1 , a coefficient of variation in cluster size of 0.54 , and the following estimates of the outcomes in the HENRY alone (standard practice) sites: $55 \%$ of centres will enrol at least eight parents per programme; $50 \%$ of centres will retain $\geq 75 \%$ of parents attending five of eight sessions.

Thus, with the anticipated number of centres (24 local authorities, 144 children's centres), we expected to have at least $80 \%$ power to detect meaningful improvements in differences of $30 \%$ in the primary endpoints at the $5 \%$ significance level if the ICC was as high as 0.1 or at least $90 \%$ power to detect the same differences if the ICC was 0.05 . Applying a Bonferroni correction to adjust for multiplicity arising from analysis of multiple primary endpoints (alpha $=2.5 \%$ ) would allow detection of a difference of $32 \%$ (slightly larger than the minimum meaningful improvement) in either of the primary endpoints if the ICC was 0.1 with at least $80 \%$ power or if the ICC was 0.05 with at least $90 \%$ power (see Additional Table 1 for scenarios).

\section{Process evaluation}

A process evaluation was undertaken alongside the trial to explore implementation, context and change mechanisms as recommended by UK Medical Research Council guidance (33). Constructs from the Linnan and Steckler process evaluation framework (34) were used to report implementation process (reach, dose delivered, dose received, and recruitment) and context. A theory based approach was used to explore the underpinning theories of change (35). A variety of methods was used to measure implementation of the optimisation intervention: HENRY distribution records (dose delivered); training attendance data (reach), researcher workshop observations (fidelity); self-report workshop delivery checklists (fidelity); and session evaluation forms (dose received). Contextual factors were explored via demographic questionnaires and interviews with a selection of participants from intervention and control centres (local authority commissioners, children's centre managers and HENRY facilitators). Behaviour change was assessed by measuring uptake of the recommended strategies that were measurable via 
routine process data (delivery of taster sessions, enrolling a mix of referred and self-referred participants and recruiting participant via peer support). The theories of change were explored using synthesis of the quantitative and qualitative findings.

\section{Statistical analysis}

Analyses based on intention-to-treat (ITT) were conducted in SAS software version 9.4 (SAS Institute Inc. Cary NC) according to a pre-specified analysis plan. To adjust for two primary endpoints, a Bonferroni correction was applied and a two-sided significance level of $2.5 \%$ was used for each comparison, thereby preserving the family-wise error rate of $5 \%$. All other endpoints were tested at the two-sided $5 \%$

significance level and no adjustments for multiple comparisons were made. Where centres ran more than one programme in the trial follow-up period, data from the last programmes delivered (most recent to analysis) in each centre were used in the primary analysis.

Due to the small number of clusters, a two-stage cluster-level analysis (36) of the primary outcomes was performed, adjusting for stratification factors (pre-randomisation levels of recruitment and attendance, proportion of centres delivering at least one HENRY programme in 2015, local authority size and area deprivation) (36). Firstly, logistic regression models adjusted for stratification factors, but ignoring clustering of the data, were produced and residuals were summarised by cluster. A t-test was then performed on the cluster-level summaries of the covariate-adjusted residuals. If the distribution of the cluster-level summaries was skewed, the logarithm of the cluster-level summaries were used. Secondary outcomes were analysed using the same methods as the primary outcomes (with the exception of family eating behaviours and longitudinal impact on enrolment and attendance). Where applicable, secondary outcome models adjusted for the stratification factors, the change in the outcome at baseline (post programme - pre programme for the pre-randomisation programme) and the change in outcome at trial follow-up (i.e. for parent compliance, the model adjusted for the baseline change in parent reported child intake of fruits and vegetables and parent reported child intake of fruits and vegetables). ICCs were calculated using mixed effects models adjusted for the stratification factors. Missing item-level data was imputed for the self-efficacy measure using the half rule because this was the only continuous outcome measure where multiple items were summed to calculate a total score (37). Missing data were not imputed for any other measures or for the primary outcomes (38); if a children's centre did not deliver a HENRY programme during the trial (post-randomisation) they were still included in the analysis, under ITT, and classified as not having met the enrolment or attendance target.

\section{Changes to methods after trial registration}

A six-month period for training of the optimisation intervention was added prior to the trial 12-month trial intervention delivery period in which HENRY programmes were delivered at participating children's centres (extending the follow-up to 18 months post randomisation). In addition, our original protocol stated that we would conduct a full cost-benefit analysis of the optimisation intervention. However, subsequent null trial findings indicated that this was not appropriate. Instead, a discrete choice study (39) was conducted to consider, more widely, what delivery elements of obesity prevention programmes are most valued by 
commissioners (40). The sample size within the published protocol did not allow for analysis of two primary endpoints and incorrectly included reference to a single composite endpoint. This has been updated both in the text and in Additional Table 1.

\section{Results}

The HENRY plus optimisation arm delivered HENRY as standard, in addition to the optimisation intervention (20). The Behaviour Change Wheel (BCW) framework (28) guided the development of the intervention which aimed to support local authorities and children's centres to promote parent engagement by encouraging them to adopt recommended engagement strategies (Table 1). The intervention used a multi-level approach to change behaviours at multiple organisational levels within the children's centre context. Intervention components and materials were designed by the HENRY central team who have expertise in intervention design and delivery. A trainer from the central HENRY team provided optimisation intervention training to local authority HENRY coordinators (responsible for coordinating HENRY activities within their area) who implemented the intervention locally. HENRY coordinators typically have a background in health/public health intervention delivery. 
Table 1

Recommended strategies for promoting parent engagement with HENRY

\section{Parent engagement strategies}

1. Hold taster sessions prior to each HENRY programme provision for centre staff

\section{Rationale}

Potential participants are more likely to engage if they have a greater understanding of what the programme entails
Informed by

Experience of HENRY personnel, ethnography study finding (observation) and the literature e.g. (51)
2. Increase HENRY training

Some children's centre staff lack basic knowledge of the content of the HENRY programme and would benefit from training on the HENRY approach

3. Hold HENRY programmes regularly and plan far in advance
Some HENRY programmes are planned at short notice which hinders recruitment efforts
Ethnography study (interviews and observation), experience of team members and the literature e.g. (52-56)

Ethnography study (informal conversations) and experience of intervention development team

\section{Promote HENRY widely within} Centre using a range of methods
There is a general lack of awareness of HENRY among visiting parents
Ethnography study (observations, informal conversations and parent focus groups)

Ethnography study (interviews and observations) and the literature (57)
5. Allow a mix of referred and selfreferred parents to enrol
Delivering programmes to a mix of parents (referred and selfreferred) reduces barriers associated with stigma and improves group dynamics

6. Encourage parents that have attended HENRY to recruit their peers
Parents are more likely to attend a programme if they know someone that has attended before
Ethnography study (interviews and focus groups) and the literature e.g. $(58,59)$
7. Adopt a whole centre approach to HENRY; whereby HENRY is well supported in the centre and HENRY principles are adopted in other programmes.
Adopting a whole centre approach to HENRY implementation achieves better outcomes for engagement
Ethnography study (observations and informal conversations) and experience of the intervention development team

Ethnography study

Misconceptions around what

8. Promote HENRY accurately to dispel myths about HENRY being a healthy eating programme

9. Ensure parents feel comfortable when attending the session
HENRY entails may deter people from engaging

The skills of facilitators are known to influence engagement (interviews, observations, focus group and informal interviews)

Ethnography study (observation, focus groups and interviews) and the literature $(30,31$, 60-63) 


\begin{tabular}{|lll|}
\hline Parent engagement strategies & Rationale & Informed by \\
\hline $\begin{array}{l}\text { 10. Follow up on all parents that } \\
\text { miss a session to encourage } \\
\text { continued attendance }\end{array}$ & $\begin{array}{l}\text { Participants feel valued if they are } \\
\text { followed up after missing a } \\
\text { session }\end{array}$ & $\begin{array}{l}\text { Ethnography study (focus } \\
\text { groups) and experience of } \\
\text { the intervention } \\
\text { development team. }\end{array}$ \\
\hline
\end{tabular}

Table 2 summarises the components of the optimisation intervention in line with guidance for intervention description reporting (29). These are aimed at changing the behaviours of local authority commissioners, children's centre managers, children's centre staff, HENRY facilitators, and previous participants of HENRY. 
Table 2

Intervention components for the optimised parent engagement intervention

$\begin{array}{llll}\begin{array}{l}\text { Intervention } \\ \text { component }\end{array} & \text { Description Recipient } & \text { Procedure When }\end{array}$

\section{HENRY} outcome report
Report provided local authority level outcome data compiled from programmes delivered in the previous school term.

Outcomes include; enrolment and completion data, participant feedback, participant reported behaviour change e.g. parenting efficacy and healthy lifestyles)

\section{Commissioner} overview leaflet

Leaflet provided the
following information:
- Brief description of HENRY and proposed outcomes for families

- The aim of the optimisation intervention

- Description of intervention activities

- Description of recommended strategies relevant to commissioners (Table 1 strategies: 1, 2,5 \&6) and expected benefits

Dashboard report

$\begin{array}{ll}\text { One-page report } & \text { Children's } \\ \text { summarising key } & \text { centre } \\ \text { programme level } & \text { managers }\end{array}$
outcomes e.g. emotional well-being, parenting efficacy and diet and physical activity

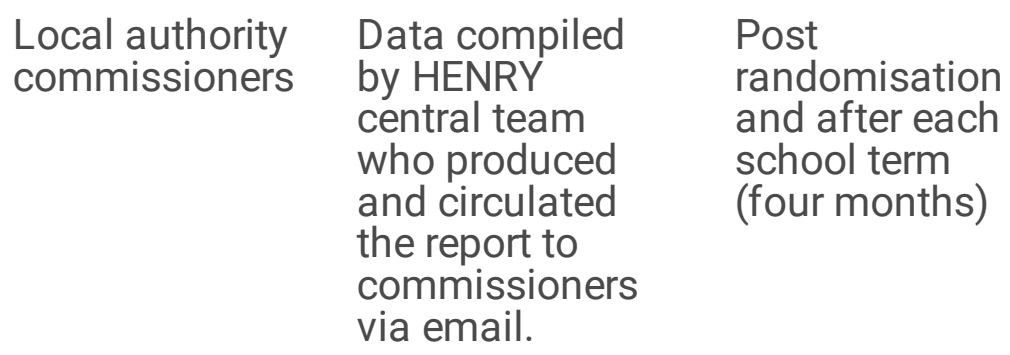

Local authority Data compiled commissioners

by HENRY central team who produced and circulated the report to commissioners via email.

Post randomisation and after each school term (four months)

\section{Local authority commissioners \\ Circulated by central HENRY team to commissioners via email}

Post randomisation

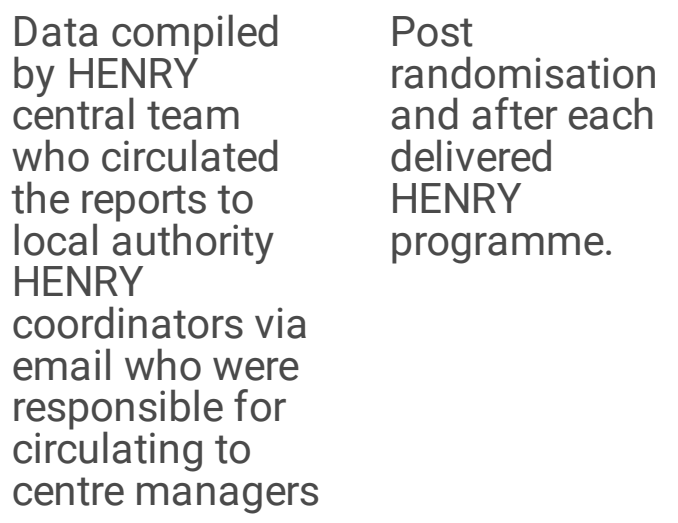




\begin{tabular}{|c|c|c|c|c|}
\hline $\begin{array}{l}\text { Intervention } \\
\text { component }\end{array}$ & Description & Recipient & Procedure & When \\
\hline $\begin{array}{l}\text { Manager } \\
\text { information } \\
\text { workshop }\end{array}$ & $\begin{array}{l}\text { Interactive group } \\
\text { workshops for managers } \\
\text { to learn about the benefits } \\
\text { of adopting relevant } \\
\text { engagement strategies } \\
\text { (Table } 1 \text { strategies 1-8). } \\
\text { One full day workshop } \\
\text { delivered in each } \\
\text { participating area } \\
\text { incorporating group } \\
\text { discussion and activities. } \\
\text { Content covered three } \\
\text { themes; increasing the } \\
\text { profile of HENRY, } \\
\text { widening the reach of } \\
\text { HENRY and programme } \\
\text { planning }\end{array}$ & $\begin{array}{l}\text { Children's } \\
\text { centre } \\
\text { managers }\end{array}$ & $\begin{array}{l}\text { Local authority } \\
\text { HENRY } \\
\text { coordinators } \\
\text { delivered the } \\
\text { workshops at a } \\
\text { local venue after } \\
\text { receiving training } \\
\text { from central } \\
\text { HENRY office. }\end{array}$ & $\begin{array}{l}\text { Post } \\
\text { randomisation }\end{array}$ \\
\hline $\begin{array}{l}\text { Facilitator } \\
\text { refresher } \\
\text { training }\end{array}$ & $\begin{array}{l}\text { Interactive workshop for } \\
\text { HENRY facilitators to } \\
\text { learn about the expected } \\
\text { benefits of adopting } \\
\text { relevant engagement } \\
\text { strategies (Table } 1 \\
\text { strategies } 6,9 \& 10) \text {. } \\
\text { One full day workshop } \\
\text { was delivered in each } \\
\text { participating area } \\
\text { incorporating group } \\
\text { discussion and activities. } \\
\text { Content covered two } \\
\text { themes; HENRY } \\
\text { recruitment and meeting } \\
\text { the needs of the group. }\end{array}$ & $\begin{array}{l}\text { HENRY } \\
\text { facilitators }\end{array}$ & $\begin{array}{l}\text { Local authority } \\
\text { HENRY } \\
\text { coordinators } \\
\text { delivered the } \\
\text { workshops at a } \\
\text { local venue after } \\
\text { receiving training } \\
\text { from central } \\
\text { HENRY office. }\end{array}$ & $\begin{array}{l}\text { Post } \\
\text { randomisation }\end{array}$ \\
\hline $\begin{array}{l}\text { Revised } \\
\text { promotional } \\
\text { material } \\
\text { (leaflets and } \\
\text { posters) }\end{array}$ & $\begin{array}{l}\text { Revised promotional } \\
\text { material promoting } \\
\text { parenting aspects of } \\
\text { HENRY and reducing } \\
\text { emphasis on health, } \\
\text { exercise and nutrition }\end{array}$ & $\begin{array}{l}\text { Children's } \\
\text { centre staff } \\
\text { and potential } \\
\text { participants }\end{array}$ & $\begin{array}{l}\text { Local authority } \\
\text { HENRY } \\
\text { coordinators } \\
\text { distributed } \\
\text { promotional } \\
\text { material to } \\
\text { centres to } \\
\text { promote HENRY } \\
\text { to potential } \\
\text { participants }\end{array}$ & $\begin{array}{l}\text { Post } \\
\text { randomisation } \\
\text { and } \\
\text { throughout } \\
\text { follow up } \\
\text { period }\end{array}$ \\
\hline
\end{tabular}

\section{Outcomes}

All local authorities which commission and deliver HENRY routinely provide process data to the central HENRY office for monitoring and quality assurance. Except for qualitative data collected for the process 
evaluation, this trial only used these routine HENRY data.

Anonymised data that were transferred to the CTRU included: Recruitment and attendance data for programmes run pre-randomisation (baseline) and follow-up (programmes run for a 12 month period after training (6 months)); optimisation intervention training attendance and implementation data (e.g. dates, certification, numbers); and anonymised parent level data (child gender, age, ethnicity, the number and age of children under five in the home and questionnaire data (below)). As families usually only attend one HENRY programme, demographic characteristics differ at each time point.

\section{Primary}

The multiple primary outcomes were: i) the proportion of centres enrolling at least eight parents per programme and ii) the proportion of centres with at least $75 \%$ of parents attending a minimum of five out of eight sessions per programme. The optimisation intervention was to be considered to be effective if either the enrolment or retention goals were met.

\section{Secondary}

The pre-specified secondary outcomes were:

1. Parental adherence as measured via the proxy measure: proportion of parents reporting an increase of 0.5 in the daily frequency of consumption of fruits and vegetables by children per programme as measured by the modified and reduced Food Frequency questionnaire (30).

2. Proportion of children's centres achieving all targets for enrolment, attendance and parent compliance.

3. Assessment of parenting self-efficacy as measured by a modified Parenting Self-Agency questionnaire prior to staring HENRY (pre-programme) and eight weeks later upon completion of the programme (post-programme) $(30,31)$.

4. Assessment of family eating behaviours as measured by a modified Golan Family Eating and Activity Habits questionnaire (pre and post-programme) $(30,32)$.

5. Assessment of family activity as measured by a bespoke HENRY questionnaire (pre and postprogramme).

6. Assessment of child screen time as measured by a bespoke HENRY questionnaire (pre and postprogramme).

7. Assessment of intake of key indicator foods as measured by a modified Food Frequency questionnaire (pre and post-programme) (30).

8. Longitudinal impact on enrolment and attrition assessed in children's centres which provide data from more than one programme.

\section{Sample Size}

Power calculations for a fixed sample size were conducted to examine the anticipated power for various intervention effects, in each of the primary outcomes and adjusting for multiplicity (see Additional 
Table 1 for scenarios). We assumed $25 \%$ of the 32 local authorities delivering HENRY would be ineligible or would opt out of the trial, leaving 24 local authorities (12 per arm). Based on data from previous HENRY programmes (2014), we assumed an average of 6 children's centres per local authority, providing a total of 144 children's centres (72 per arm), an intra-cluster correlation coefficient (ICC) between 0.05 and 0.1 , a coefficient of variation in cluster size of 0.54 , and the following estimates of the outcomes in the HENRY alone (standard practice) sites: $55 \%$ of centres will enrol at least eight parents per programme; $50 \%$ of centres will retain $\geq 75 \%$ of parents attending five of eight sessions.

Thus, with the anticipated number of centres (24 local authorities, 144 children's centres), we expected to have at least $80 \%$ power to detect meaningful improvements in differences of $30 \%$ in the primary endpoints at the $5 \%$ significance level if the ICC was as high as 0.1 or at least $90 \%$ power to detect the same differences if the ICC was 0.05 . Applying a Bonferroni correction to adjust for multiplicity arising from analysis of multiple primary endpoints (alpha $=2.5 \%$ ) would allow detection of a difference of $32 \%$ (slightly larger than the minimum meaningful improvement) in either of the primary endpoints if the ICC was 0.1 with at least $80 \%$ power or if the ICC was 0.05 with at least $90 \%$ power (see Additional Table 1 for scenarios).

\section{Process Evaluation}

\section{Implementation}

Implementation of the optimisation intervention varied between local authorities and was delivered in full in just four out of the ten local authorities (40\%) which hindered its ability to instigate behaviour change and hence promote parental engagement. The commissioner overview leaflet was delivered to all but one local authority $(90 \%)$ but the commissioner outcome report was delivered the appropriate time points in just three local authorities (30\%). Dashboard reports were not delivered at the appropriate time points in any of the local authorities. Manager workshops were delivered in the specified format in $40 \%$ of local authorities. Workshop delivery checklists were received from four out of seven workshops reporting that two delivered $100 \%$ of the specified behaviour change techniques, one delivered $78 \%$ but one local authority delivered only $40 \%$. Facilitator workshops were delivered in the specified format in five local authorities (50\%): delivery checklists were received from all workshops with all reporting that $100 \%$ of behaviour change techniques were delivered. Uptake of the re-branded promotional material was lower than expected, with just four local authorities (40\%) using the materials.

\section{Changes To Methods After Trial Registration}

A six-month period for training of the optimisation intervention was added prior to the trial 12-month trial intervention delivery period in which HENRY programmes were delivered at participating children's centres (extending the follow-up to 18 months post randomisation). In addition, our original protocol stated that we would conduct a full cost-benefit analysis of the optimisation intervention. However, subsequent null trial findings indicated that this was not appropriate. Instead, a discrete choice study (39) was conducted to consider, more widely, what delivery elements of obesity prevention programmes are most valued by commissioners (40). The sample size within the published protocol did not allow for analysis of two 
primary endpoints and incorrectly included reference to a single composite endpoint. This has been updated both in the text and in Additional Table 1.

Table 3. Local Authority pre-randomisation characteristics by arm

\begin{tabular}{|c|c|c|c|}
\hline & $\begin{array}{l}\text { HENRY } \\
\text { alone } \\
(n=10)\end{array}$ & $\begin{array}{c}\text { HENRY + } \\
\text { Optimisation } \\
\text { Intervention } \\
(n=10)\end{array}$ & $\begin{array}{l}\text { Total } \\
(\mathrm{n}=20)\end{array}$ \\
\hline Number of children's centres & 65 & 61 & 126 \\
\hline \multicolumn{4}{|c|}{$\begin{array}{l}\text { Proportion of children's centres meeting the recruitment } \\
\text { target of at least } 8 \text { parents per programme }\end{array}$} \\
\hline Mean (SD) & $\begin{array}{c}0.5 \\
(0.3)\end{array}$ & $0.6(0.3)$ & $\begin{array}{c}0.5 \\
(0.3)\end{array}$ \\
\hline \multicolumn{4}{|c|}{$\begin{array}{l}\text { Proportion of children's centres meeting the attendance } \\
\text { target of at least } 75 \% \text { parents attending } 5 / 8 \text { sessions per } \\
\text { programme }\end{array}$} \\
\hline Mean (SD) & $\begin{array}{c}0.5 \\
(0.3)\end{array}$ & $0.5(0.3)$ & $\begin{array}{c}0.5 \\
(0.3)\end{array}$ \\
\hline
\end{tabular}

Proportion of children's centres running at least one HENRY programme in 2015

Mean (SD)
0.7
$(0.3)$
$0.8(0.3)$
0.7
$(0.3)$

Size of local authority

Less than the median number of children's centres per local authority

More than the median number of children's centres per local authority

$\begin{array}{ccc}5 & 5(50.0 \%) & 10 \\ (50.0 \%) & & (50.0 \%) \\ 5 & 5(50.0 \%) & 10 \\ (50.0 \%) & & (50.0 \%)\end{array}$

Proportion of children's centres in the most deprived quintile

Mean (SD)
0.6
$(0.4)$
$0.6(0.3)$
0.6
$(0.3)$

Proportion of children's centres in the least deprived quintile

Mean (SD)
0.0
$(0.1)$
$0.0(0.1)$
0.0
$(0.1)$ 
Demographic characteristics for the 881 parents enrolled into HENRY programmes pre-randomisation were generally balanced by arm although some imbalances in ethnicity were evident (Table 4). There was a high volume of individual level routine data missing: 24 children's centres were unable to provide questionnaire data for their parents and for centres which provided data, not all data were available for some parents enrolled onto programmes. Reasons for missing questionnaire data included: invalid for processing $(n=19)$; not returned to central office $(n=3)$; incorrect measures used $(n=2)$. Where parent questionnaire data was available, most parents were female, aged between 25-64 years and had heard about the HENRY programme via professional referral (e.g. children's centre staff, health visitor, family support worker). Demographic characteristics for local authorities are presented in Additional Tables 2 to 6. 
Table 4

Participant characteristics by arm

\section{Pre-randomisation}

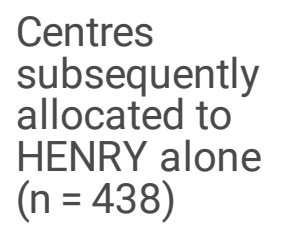

$\begin{array}{ll}\begin{array}{l}\text { Centres } \\ \text { subsequently }\end{array} & \begin{array}{l}\text { Total } \\ (\mathrm{n}=\end{array} \\ \text { allocated to } & 881) \\ \text { HENRY }+ & \\ \text { Optimisation } & \\ \text { intervention ( } & \\ =443) & \end{array}$

Follow-up

$\begin{array}{lll}\begin{array}{l}\text { Centres } \\ \text { delivering }\end{array} & \begin{array}{l}\text { Centres } \\ \text { delivering }\end{array} & \begin{array}{l}\text { Total } \\ (\mathrm{n}=\end{array} \\ \text { HENRY } & \text { HENRY }+ & 433) \\ \text { alone }(\mathrm{n} & \begin{array}{l}\text { Optimisation } \\ \text { intervention } \\ (\mathrm{n}=213)\end{array} & \\ & & \end{array}$

\begin{tabular}{|c|c|c|c|c|c|c|}
\hline Male & $13(3.0 \%)$ & $9(2.0 \%)$ & $\begin{array}{l}22 \\
(2.5 \%)\end{array}$ & $8(3.8 \%)$ & $3(1.4 \%)$ & $\begin{array}{l}11 \\
(2.5 \%)\end{array}$ \\
\hline Female & $219(50.0 \%)$ & 215 (48.5\%) & $\begin{array}{l}434 \\
(49.3 \%)\end{array}$ & $\begin{array}{l}120 \\
(56.3 \%)\end{array}$ & $112(50.9 \%)$ & $\begin{array}{l}232 \\
(53.6 \%)\end{array}$ \\
\hline $\begin{array}{l}\text { Prefer not to } \\
\text { say }\end{array}$ & $4(0.9 \%)$ & $4(0.9 \%)$ & $\begin{array}{l}8 \\
(0.9 \%)\end{array}$ & $0(0.0 \%)$ & $2(0.9 \%)$ & $\begin{array}{l}2 \\
(0.5 \%)\end{array}$ \\
\hline Missing & $202(46.1 \%)$ & 215 (48.5\%) & $\begin{array}{l}417 \\
(47.3 \%)\end{array}$ & $\begin{array}{l}85 \\
(39.9 \%)\end{array}$ & $103(46.8 \%)$ & $\begin{array}{l}188 \\
(43.4 \%)\end{array}$ \\
\hline
\end{tabular}

Parent age

\begin{tabular}{|c|c|c|c|c|c|c|}
\hline Under 18 & $0(0.0 \%)$ & $0(0.0 \%)$ & $\begin{array}{l}0 \\
(0.0 \%)\end{array}$ & $0(0.0 \%)$ & $0(0.0 \%)$ & $\begin{array}{l}0 \\
(0.0 \%)\end{array}$ \\
\hline 18-25yrs & 46 (10.5\%) & $36(8.1 \%)$ & $\begin{array}{l}82 \\
(9.3 \%)\end{array}$ & $20(9.4 \%)$ & 16 (7.3\%) & $\begin{array}{l}36 \\
(8.3 \%)\end{array}$ \\
\hline 25-64yrs & 185 (42.2\%) & 185 (41.8\%) & $\begin{array}{l}370 \\
(42.0 \%)\end{array}$ & $\begin{array}{l}107 \\
(50.2 \%)\end{array}$ & 99 (45.0\%) & $\begin{array}{l}206 \\
(47.6 \%)\end{array}$ \\
\hline 65yrs+ & $2(0.5 \%)$ & $2(0.5 \%)$ & $\begin{array}{l}4 \\
(0.5 \%)\end{array}$ & $0(0.0 \%)$ & $1(0.5 \%)$ & $\begin{array}{l}1 \\
(0.2 \%)\end{array}$ \\
\hline $\begin{array}{l}\text { Prefer not to } \\
\text { say }\end{array}$ & $3(0.7 \%)$ & $5(1.1 \%)$ & $\begin{array}{l}8 \\
(0.9 \%)\end{array}$ & $1(0.5 \%)$ & $1(0.5 \%)$ & $\begin{array}{l}2 \\
(0.5 \%)\end{array}$ \\
\hline Missing & 202 (46.1\%) & 215 (48.5\%) & $\begin{array}{l}417 \\
(47.3 \%)\end{array}$ & $\begin{array}{l}85 \\
(39.9 \%)\end{array}$ & 103 (46.8\%) & $\begin{array}{l}188 \\
(43.4 \%)\end{array}$ \\
\hline $\begin{array}{l}\text { Number of } \\
\text { children }^{\$}\end{array}$ & $n=232$ & $n=282$ & $n=514$ & $n=183$ & $n=169$ & $n=352$ \\
\hline
\end{tabular}

$\$$ Collected as the number of children of each age per parent, numbers reported therefore total more than the number of parents pre-randomisation / follow-up.

*Routine data were missing for 417 parents pre-randomisation and 188 parents at follow-up. 


\begin{tabular}{|c|c|c|c|c|c|c|}
\hline \multirow[b]{2}{*}{$<1 \mathrm{yrs}^{*}$} & \multicolumn{3}{|c|}{ Pre-randomisation } & \multicolumn{3}{|l|}{ Follow-up } \\
\hline & $65(28.0 \%)$ & $68(24.1 \%)$ & $\begin{array}{l}133 \\
(25.9 \%)\end{array}$ & $\begin{array}{l}43 \\
(23.5 \%)\end{array}$ & $34(20.1 \%)$ & $\begin{array}{l}77 \\
(21.9 \%)\end{array}$ \\
\hline $1 y r{ }^{*}$ & $5925.4 \%)$ & $7125.2 \%)$ & $\begin{array}{l}130 \\
(25.3 \%)\end{array}$ & $\begin{array}{l}41 \\
(22.4 \%)\end{array}$ & 38 (22.5\%) & $\begin{array}{l}79 \\
(22.4 \%)\end{array}$ \\
\hline $2 \mathrm{yrs}^{*}$ & $34(14.7 \%)$ & $43(15.2 \%)$ & $\begin{array}{l}77 \\
15.0 \%)\end{array}$ & $\begin{array}{l}29 \\
(15.8 \%)\end{array}$ & $31(18.3 \%)$ & $\begin{array}{l}60 \\
(17.0 \%)\end{array}$ \\
\hline $3 y r s^{*}$ & $34(14.7 \%)$ & $36(12.8 \%)$ & $\begin{array}{l}70 \\
(13.6 \%)\end{array}$ & $\begin{array}{l}28 \\
(15.3 \%)\end{array}$ & $29(17.2 \%)$ & $\begin{array}{l}57 \\
(16.2 \%)\end{array}$ \\
\hline $4 y r s^{*}$ & $27(11.6 \%)$ & $38(13.5 \%)$ & $\begin{array}{l}65 \\
(12.6 \%)\end{array}$ & $\begin{array}{l}25 \\
(13.7 \%)\end{array}$ & $15(8.9 \%)$ & $\begin{array}{l}40 \\
(11.4 \%)\end{array}$ \\
\hline $5 y r s^{*}$ & $13(5.6 \%)$ & $26(9.2 \%)$ & $\begin{array}{l}39 \\
(7.6 \%)\end{array}$ & $17(9.3 \%)$ & $22(13.0 \%)$ & $\begin{array}{l}39 \\
(11.1 \%)\end{array}$ \\
\hline \multicolumn{7}{|l|}{ Ethnicity } \\
\hline African & $7(1.6 \%)$ & $15(3.4 \%)$ & $22.5 \%)$ & $8(3.8 \%)$ & $5(2.3 \%)$ & $\begin{array}{l}13 \\
(3.0 \%)\end{array}$ \\
\hline Arab & $1(0.2 \%)$ & $0(0.0 \%)$ & 1 & $0(0.0 \%)$ & $2(0.9 \%)$ & $\begin{array}{l}2 \\
(0.5 \%)\end{array}$ \\
\hline Bangladeshi & $2(0.5 \%)$ & $9(2.0 \%)$ & $\begin{array}{l}11 \\
(1.2 \%)\end{array}$ & $2(0.9 \%)$ & $3(1.4 \%)$ & $\begin{array}{l}5 \\
(1.2 \%)\end{array}$ \\
\hline Black UK & $5(1.1 \%)$ & $1(0.2 \%)$ & $\begin{array}{l}6 \\
(0.7 \%)\end{array}$ & $1(0.5 \%)$ & $1(0.5 \%)$ & $\begin{array}{l}2 \\
(0.5 \%)\end{array}$ \\
\hline Caribbean & $1(0.2 \%)$ & $6(1.4 \%)$ & $\begin{array}{l}7 \\
(0.8 \%)\end{array}$ & $2(0.9 \%)$ & $2(0.9 \%)$ & $\begin{array}{l}4 \\
(0.9 \%)\end{array}$ \\
\hline Chinese & $1(0.2 \%)$ & $2(0.5 \%)$ & $\begin{array}{l}3 \\
(0.3 \%)\end{array}$ & $2(0.9 \%)$ & $0(0.0 \%)$ & $\begin{array}{l}2 \\
(0.5 \%)\end{array}$ \\
\hline $\begin{array}{l}\text { English / } \\
\text { Scottish / } \\
\text { Welsh / } \\
\text { Northern } \\
\text { Irish / UK }\end{array}$ & $181(41.3 \%)$ & $146(33.0 \%)$ & $\begin{array}{l}327 \\
(37.1 \%)\end{array}$ & $\begin{array}{l}75 \\
(35.2 \%)\end{array}$ & $61(27.7 \%)$ & $\begin{array}{l}136 \\
(31.4 \%)\end{array}$ \\
\hline $\begin{array}{l}\text { Gypsy or } \\
\text { Irish } \\
\text { Traveller }\end{array}$ & $0(0.0 \%)$ & $1(0.2 \%)$ & $\begin{array}{l}1 \\
(0.1 \%)\end{array}$ & $0(0.0 \%)$ & $0(0.0 \%)$ & $\begin{array}{l}0 \\
(0.0 \%)\end{array}$ \\
\hline Indian & $6(1.4 \%)$ & $4(0.9 \%)$ & $\begin{array}{l}10 \\
(1.1 \%)\end{array}$ & $4(1.9 \%)$ & $1(0.5 \%)$ & $\begin{array}{l}5 \\
(1.2 \%)\end{array}$ \\
\hline \multicolumn{7}{|c|}{$\begin{array}{l}\text { \$Collected as the number of children of each age per parent, numbers reported therefore total more } \\
\text { than the number of parents pre-randomisation / follow-up. }\end{array}$} \\
\hline
\end{tabular}




\begin{tabular}{|c|c|c|c|c|c|c|}
\hline & Pre-randomis & & & Follow-up & & \\
\hline Irish & $0(0.0 \%)$ & $0(0.0 \%)$ & $\begin{array}{l}0 \\
(0.0 \%)\end{array}$ & $0(0.0 \%)$ & $1(0.5 \%)$ & $\begin{array}{l}1 \\
(0.2 \%)\end{array}$ \\
\hline $\begin{array}{l}\text { Mixed ethnic } \\
\text { background }\end{array}$ & $2(0.5 \%)$ & $2(0.5 \%)$ & $\begin{array}{l}4 \\
(0.5 \%)\end{array}$ & 7 (3.3\%) & $2(0.9 \%)$ & $\begin{array}{l}9 \\
(2.1 \%)\end{array}$ \\
\hline Pakistani & 3 (0.7\%) & $12(2.7 \%)$ & $\begin{array}{l}15 \\
(1.7 \%)\end{array}$ & $5(2.3 \%)$ & $11(5.0 \%)$ & $\begin{array}{l}16 \\
(3.7 \%)\end{array}$ \\
\hline $\begin{array}{l}\text { Any other } \\
\text { Asian } \\
\text { background }\end{array}$ & $5(1.1 \%)$ & $1(0.2 \%)$ & $\begin{array}{l}6 \\
(0.7 \%)\end{array}$ & $3(1.4 \%)$ & $1(0.5 \%)$ & $\begin{array}{l}4 \\
(0.9 \%)\end{array}$ \\
\hline $\begin{array}{l}\text { Any other } \\
\text { Black / } \\
\text { African / } \\
\text { Caribbean } \\
\text { background }\end{array}$ & $1(0.2 \%)$ & $1(0.2 \%)$ & $\begin{array}{l}2 \\
(0.2 \%)\end{array}$ & $2(0.9 \%)$ & $2(0.9 \%)$ & $\begin{array}{l}4 \\
(0.9 \%)\end{array}$ \\
\hline $\begin{array}{l}\text { Any other } \\
\text { White } \\
\text { background }\end{array}$ & $13(3.0 \%)$ & $13(2.9 \%)$ & $\begin{array}{l}26 \\
(3.0 \%)\end{array}$ & $0(0.0 \%)$ & $0(0.0 \%)$ & $\begin{array}{l}0 \\
(0.0 \%)\end{array}$ \\
\hline $\begin{array}{l}\text { Any other } \\
\text { ethnic group }\end{array}$ & $3(0.7 \%)$ & $3(0.7 \%)$ & $\begin{array}{l}6 \\
(0.7 \%)\end{array}$ & $0(0.0 \%)$ & $9(4.1 \%)$ & $\begin{array}{l}9 \\
(2.1 \%)\end{array}$ \\
\hline $\begin{array}{l}\text { Prefer not to } \\
\text { say }\end{array}$ & $5(1.1 \%)$ & $12(2.7 \%)$ & $\begin{array}{l}17 \\
(1.9 \%)\end{array}$ & 7 (3.3\%) & 5 (2.3\%) & $\begin{array}{l}12 \\
(2.8 \%)\end{array}$ \\
\hline Missing & 202 (46.1\%) & 215 (48.5\%) & $\begin{array}{l}417 \\
(47.3 \%)\end{array}$ & $\begin{array}{l}95 \\
(44.6 \%)\end{array}$ & 114 (51.8\%) & $\begin{array}{l}209 \\
(48.3 \%)\end{array}$ \\
\hline \multicolumn{7}{|l|}{$\begin{array}{l}\text { How did } \\
\text { parents hear } \\
\text { about the } \\
\text { HENRY } \\
\text { programme? }\end{array}$} \\
\hline $\begin{array}{l}\text { Family and } \\
\text { friends }\end{array}$ & $10(2.3 \%)$ & $4(0.9 \%)$ & $\begin{array}{l}14 \\
(1.6 \%)\end{array}$ & $9(4.2 \%)$ & $5(2.3 \%)$ & $\begin{array}{l}14 \\
(3.2 \%)\end{array}$ \\
\hline Leaflet & $10(2.3 \%)$ & $15(3.4 \%)$ & $\begin{array}{l}25 \\
(2.8 \%)\end{array}$ & $14(6.6 \%)$ & $10(4.5 \%)$ & $\begin{array}{l}24 \\
(5.5 \%)\end{array}$ \\
\hline Poster & $5(1.1 \%)$ & $2(0.5 \%)$ & $\begin{array}{l}7 \\
(0.8 \%)\end{array}$ & 7 (3.3\%) & $2(0.9 \%)$ & $\begin{array}{l}9 \\
(2.1 \%)\end{array}$ \\
\hline Professional & 63 (14.4\%) & 46 (10.4\%) & $\begin{array}{l}109 \\
(12.4 \%)\end{array}$ & $\begin{array}{l}89 \\
(41.8 \%)\end{array}$ & $74(33.6 \%)$ & $\begin{array}{l}163 \\
(37.6 \%)\end{array}$ \\
\hline
\end{tabular}

\$Collected as the number of children of each age per parent, numbers reported therefore total more than the number of parents pre-randomisation / follow-up.

*Routine data were missing for 417 parents pre-randomisation and 188 parents at follow-up. 


\begin{tabular}{|c|c|c|c|c|c|c|}
\hline \multirow[b]{2}{*}{ Website } & \multicolumn{3}{|c|}{ Pre-randomisation } & \multicolumn{3}{|c|}{ Follow-up } \\
\hline & $2(0.5 \%)$ & $1(0.2 \%)$ & $\begin{array}{l}3 \\
(0.3 \%)\end{array}$ & $1(0.5 \%)$ & $0(0.0 \%)$ & $\begin{array}{l}1 \\
(0.2 \%)\end{array}$ \\
\hline Other & $10(2.3 \%)$ & $18(4.1 \%)$ & $\begin{array}{l}28 \\
(3.2 \%)\end{array}$ & $8(3.8 \%)$ & $15(6.8 \%)$ & $\begin{array}{l}23 \\
(5.3 \%)\end{array}$ \\
\hline Missing & 338 (77.2\%) & 357 (80.6\%) & $\begin{array}{l}695 \\
(78.9 \%)\end{array}$ & $\begin{array}{l}85 \\
(39.9 \%)\end{array}$ & $114(51.8 \%)$ & $\begin{array}{l}199 \\
(46.0 \%)\end{array}$ \\
\hline \multicolumn{7}{|c|}{$\begin{array}{l}\text { \$Collected as the number of children of each age per parent, numbers reported therefore total more } \\
\text { than the number of parents pre-randomisation / follow-up. }\end{array}$} \\
\hline
\end{tabular}


Table 5

Primary outcomes: pre-randomisation proportions, outcome proportions and risk differences adjusted for stratification factors

\begin{tabular}{|c|c|c|c|c|c|c|c|}
\hline & \multirow{2}{*}{$\begin{array}{l}\text { Pre- } \\
\text { randomisation } \\
\text { (\%) }\end{array}$} & \multicolumn{3}{|c|}{$\begin{array}{l}\text { Unadjusted model } \\
\text { estimates }^{\mathrm{b}}\end{array}$} & \multicolumn{3}{|c|}{$\begin{array}{l}\text { Adjusted model } \\
\text { estimates }\end{array}$} \\
\hline & & $\begin{array}{l}\text { Outcome } \\
\text { (\%) }\end{array}$ & $\begin{array}{l}\text { RD } \\
(95 \% \\
\text { Cl) }\end{array}$ & $\begin{array}{l}\text { p- } \\
\text { value }\end{array}$ & $\begin{array}{l}\text { RD } \\
(95 \% \\
\text { Cl) }\end{array}$ & $\begin{array}{l}\text { p- } \\
\text { value }\end{array}$ & ICC \\
\hline \multicolumn{8}{|l|}{$\begin{array}{l}\text { Primary outcome 1: } \\
\text { Enrolment }\end{array}$} \\
\hline $\begin{array}{l}\text { HENRY alone }(n=10 \\
\text { local authorities) }\end{array}$ & 50.0 & 18.0 & $\begin{array}{l}-0.3 \\
(-19.1 \\
18.6)\end{array}$ & 0.978 & $\begin{array}{l}-1.2 \\
(-19.5 \\
17.1)\end{array}$ & 0.886 & 0.136 \\
\hline $\begin{array}{l}\text { HENRY + Optimisation } \\
\text { Intervention }(n=10 \\
\text { local authorities })\end{array}$ & 60.0 & 17.8 & & & & & \\
\hline \multicolumn{8}{|l|}{$\begin{array}{l}\text { Primary outcome } 2 \text { : } \\
\text { Attendance }\end{array}$} \\
\hline $\begin{array}{l}\text { HENRY alone }(n=10 \\
\text { local authorities) }\end{array}$ & 50.0 & 13.9 & $\begin{array}{l}3.1 \\
(-13.3 \\
19.6)\end{array}$ & 0.695 & $\begin{array}{l}1.2 \\
(-15.7 \\
18.1)\end{array}$ & 0.881 & $<.001$ \\
\hline $\begin{array}{l}\text { HENRY + Optimisation } \\
\text { Intervention }(n=10 \\
\text { local authorities })\end{array}$ & 50.0 & 17.1 & & & & & \\
\hline \multicolumn{8}{|c|}{${ }^{\mathrm{a} C}$ Calculation of outcomes used data provided for randomisation } \\
\hline \multicolumn{8}{|c|}{$\begin{array}{l}{ }^{\mathrm{b}} \text { Calculation of outcomes used data from the most recently delivered HENRY programme during } \\
\text { follow-up at } 18 \text { months post randomisation }\end{array}$} \\
\hline \multicolumn{8}{|c|}{$\begin{array}{l}\text { 'Variables controlled for in the adjusted analyses were as follows: proportion of Children's Centres } \\
\text { recruiting at least } 8 \text { parents per programme at randomisation, proportion of Children's Centres } \\
\text { retaining at least } 75 \% \text { of parents for a minimum of } 5 / 8 \text { sessions per programme at randomisation, } \\
\text { proportion of Children's Centres running at least one HENRY programme in } 2015 \text {, size of local } \\
\text { authority, proportion of Children's Centres in the least / most deprived quintile as ranked by the } 2015 \\
\text { Index of Multiple Deprivation at the Lower Layer Super Output Area }\end{array}$} \\
\hline
\end{tabular}

\section{Intervention Delivery}

Outcomes were assessed during delivery of HENRY programmes between 1st September 2016 and 30th August 2017. Fifty-two of 126 (41\%) children's centres (26 HENRY + optimisation; 26 HENRY alone) from seventeen (85\%) local authorities delivered at least one HENRY programme. Of the remaining seventyfour children's centres, 35 of 61 centres (57\%) from one local authority in the HENRY + Optimisation 
intervention group, and 39 of 65 children's centres (60\%) from two local authorities in the HENRY alone arm, did not deliver a HENRY programme.

Seventy-four centres did not deliver HENRY predominantly because local authorities scheduled a reduced number of programmes (for parents across the local authority to attend) rather than scheduling delivery in every centre $(n=25)$. Other reasons provided included: HENRY programmes on hold due to "major restructuring" or "upheaval in centres" $(n=17)$; HENRY being scaled down or de-commissioned $(n=7)$; lack of HENRY facilitators in post $(n=4)$; limited resources $(n=3)$ or centre closure $(n=3)$. Ten centres did not provide a reason and five centres cancelled HENRY programmes due to low uptake. No local authorities or children's centres actively withdrew from the trial.

Participant characteristics were broadly similar to those observed pre-randomisation and similar quantities of missing data were observed overall; however, parents in the HENRY alone arm had less missing data compared to the HENRY + Optimisation intervention (Table 4). Demographic characteristics for local authorities are presented in Additional Tables.

\section{Primary Analysis}

Post randomisation primary outcomes did not differ significantly between the groups: proportion of children's centres enrolling at least eight parents per programme (adjusted Risk Difference $=-1.2 \%, 95 \%$ $\mathrm{Cl}=-19.5 \%, 17.1 \%, \mathrm{p}=0.886$ ); proportion of children's centres with at least $75 \%$ of parents attending $5 / 8$ sessions per programme (adjusted Risk Difference $=1.2 \%, 95 \% \mathrm{Cl}=-15.7 \%, 18.1 \%, \mathrm{p}=0.881$ ) (Table 5).

\section{Secondary Analysis}

There was little evidence of any intervention effects for any secondary outcomes (Additional Tables 1219). Missing data was substantial for parent reported secondary outcomes; routinely collected questionnaire data was available for $245(56 \%)$ parents pre / post-programme $(60 \%$ HENRY alone vs. $53 \%$ HENRY + optimisation intervention) compared to 881 (100\%) of parents pre-randomisation.

\section{Behaviour Change}

Routine data on the uptake of optimisation strategies in centres that delivered a programme during the trial demonstrated that some centres did use some of the optimisation strategies during the trial, indicating that the intervention had the potential to change some behaviours proposed to promote engagement with HENRY (Table 6). However, the data revealed that some centres in the HENRY alone arm also independently used similar strategies. Analyses was not performed to assess behaviour change between pre-randomisation and post-randomisation so it is also possible that centres in both arms were already using the strategies pre-randomisation. Potential relationships between adoption of the strategies and parent enrolment and completion outcomes were explored but there was no indication of a causal link. 
Table 6

Number of centres adopting optimisation strategies that were measurable using process data

\begin{tabular}{|c|c|c|}
\hline & $\begin{array}{l}\text { Control N (\%) } \\
(n=26)\end{array}$ & $\begin{array}{l}\text { Intervention } N(\%) \\
(n=26)\end{array}$ \\
\hline \multicolumn{3}{|c|}{ Delivery of taster session } \\
\hline Yes & 5 (19.2) & $14(53.8)$ \\
\hline No & 20 (76.9) & $9(34.6)$ \\
\hline Missing & $1(3.8)$ & $3(11.5)$ \\
\hline \multicolumn{3}{|c|}{ Mix of referred and self-referred parents } \\
\hline Yes & $9(34.6)$ & $8(30.8)$ \\
\hline No & $8(30.8)$ & $8(30.8)$ \\
\hline Missing & $9(34.6)$ & $10(38.5)$ \\
\hline \multicolumn{3}{|c|}{ Parents recruited via peer support } \\
\hline Yes & $4(15.4)$ & $5(19.2)$ \\
\hline No & $21(80.8)$ & $16(61.5)$ \\
\hline Missing & $1(3.8)$ & $5(19.2)$ \\
\hline
\end{tabular}


Table 7

Primary outcomes: pre-randomisation proportions, outcome proportions and risk differences adjusted for stratification factors

\begin{tabular}{|c|c|c|c|c|c|c|c|}
\hline & \multirow{2}{*}{$\begin{array}{l}\text { Pre- } \\
\text { randomisation }{ }^{a} \\
(\%)\end{array}$} & \multicolumn{3}{|c|}{$\begin{array}{l}\text { Unadjusted model } \\
\text { estimates }^{\mathrm{b}}\end{array}$} & \multicolumn{3}{|c|}{$\begin{array}{l}\text { Adjusted model } \\
\text { estimates }^{\text {bc }}\end{array}$} \\
\hline & & $\begin{array}{l}\text { Outcome } \\
\text { (\%) }\end{array}$ & $\begin{array}{l}\text { RD } \\
(95 \% \\
\mathrm{Cl})\end{array}$ & $\begin{array}{l}\text { p- } \\
\text { value }\end{array}$ & $\begin{array}{l}\text { RD } \\
(95 \% \\
\mathrm{Cl})\end{array}$ & $\begin{array}{l}\text { p- } \\
\text { value }\end{array}$ & ICC \\
\hline \multicolumn{8}{|l|}{$\begin{array}{l}\text { Primary outcome 1: } \\
\text { Enrolment }\end{array}$} \\
\hline HENRY alone $(n=10)$ & 50.0 & 18.0 & $\begin{array}{l}-0.3 \\
(-19.1 \\
18.6)\end{array}$ & 0.978 & $\begin{array}{l}-1.2 \\
(-19.5 \\
17.1)\end{array}$ & 0.886 & 0.136 \\
\hline $\begin{array}{l}\text { HENRY + } \\
\text { Optimisation } \\
\text { Intervention }(n=10)\end{array}$ & 60.0 & 17.8 & & & & & \\
\hline \multicolumn{8}{|l|}{$\begin{array}{l}\text { Primary outcome } 2 \text { : } \\
\text { Attendance }\end{array}$} \\
\hline HENRY alone $(n=10)$ & 50.0 & 13.9 & $\begin{array}{l}3.1 \\
(-13.3 \\
19.6)\end{array}$ & 0.695 & $\begin{array}{l}1.2 \\
(-15.7 \\
18.1)\end{array}$ & 0.881 & $<.001$ \\
\hline $\begin{array}{l}\text { HENRY + } \\
\text { Optimisation } \\
\text { Intervention }(n=10)\end{array}$ & 50.0 & 17.1 & & & & & \\
\hline \multicolumn{8}{|c|}{${ }^{\mathrm{a} C}$ Calculation of outcomes used data provided for randomisation } \\
\hline \multicolumn{8}{|c|}{$\begin{array}{l}{ }^{\mathrm{b}} \text { Calculation of outcomes used data from the most recently delivered HENRY programme during } \\
\text { follow-up at } 18 \text { months post randomisation }\end{array}$} \\
\hline \multicolumn{8}{|c|}{$\begin{array}{l}\text { 'Variables controlled for in the adjusted analyses were as follows: proportion of Children's Centres } \\
\text { recruiting at least } 8 \text { parents per programme at randomisation, proportion of Children's Centres } \\
\text { retaining at least } 75 \% \text { of parents for a minimum of } 5 / 8 \text { sessions per programme at randomisation, } \\
\text { proportion of Children's Centres running at least one HENRY programme in } 2015 \text {, size of local } \\
\text { authority, proportion of Children's Centres in the least / most deprived quintile as ranked by the } 2015 \\
\text { Index of Multiple Deprivation at the Lower Layer Super Output Area }\end{array}$} \\
\hline
\end{tabular}

\section{Discussion}

This trial, delivered at scale across 20 local government areas of the UK, did not show any evidence of effectiveness of an intervention designed to improve parent engagement with an obesity weight prevention programme. Our process evaluation suggested that wider contextual factors undermined the 
ability of sites to prioritise and deliver both HENRY and the optimisation intervention. These factors included reduced funding and the associated reductions in service capacity, amalgamation of services, and threats to jobs. A similar trial undertaken in children's centres in 2012 testing an implementation intervention reported similar results (43); with a nested qualitative study also describing that uncertainties surrounding the future of children's centres and imminent restructuring impeded its implementation (44).

As demonstrated here, some research settings can be themselves characterised as complex, making evaluations of interventions delivered within them challenging. Therefore, bespoke or locally adapted interventions that are responsive to local context, and that are developed alongside stakeholders may achieve greater implementation fidelity $(22,45)(42)$. However, given the major cuts to children's centre services during the period of this study, where overall funding fell by 64\% from 2010 to 2018 (46), it is unlikely that any implementation intervention would have succeeded.

There remains a strong need for approaches to improve engagement with parenting interventions delivered in community settings to optimise their impact on family and child outcomes $(47,48)$. Complex interventions (like HENRY) and supporting strategies to promote their implementation, are unlikely to be viable in the absence of sufficient resources, management commitment, and organisational stability (49). Ideally, practical implementation considerations need to be integrated during the design phase of complex interventions to (ideally) make them more robust and sustainable in unfavourable fiscal and organisational climates.

We applied a novel approach to evidence generation through the conduct of a comprehensive early-phase (evidentiary) intervention enhancement and evaluation (50). This is in contrast to traditional implementation research, which would usually be conducted following the conduct of a large randomised controlled trial to determine clinical effectiveness (in this case, childhood obesity prevention). This novel approach ensures that factors which limit trial outcomes, such as low adherence, are minimised prior to dedicating the resources required to conduct a large trial which may identify no evidence of effectiveness, perhaps as a result of poor compliance.

This trial tested a novel implementation optimisation intervention which was developed using a theoretical framework, primary research in children's centres, and the wider literature on engagement methods. The use of routine data to measure outcomes allowed for greater breadth of recruitment and minimised the commitment required by intervention teams, particularly during a time when capacity within local authorities and children's centres was already stretched. Process evaluation shed light on the factors that likely hindered impact of the intervention, particularly the impact of the wider environmental changes in the setting which resulted in a reduction in engagement in both the intervention and control arms of the trial. Not only does this contribute to the literature on engagement, it also provides valuable lessons for undertaking research within early years settings.

Although the failure of the trial to detect any impact of the implementation intervention has been attributed to poor intervention fidelity and contamination, we are unable to confirm or deny its potential effectiveness even under an assumption that fidelity was high. Despite the robust intervention 
development and trial design, political and austerity measures disrupted planned implementation beyond our control. Given that our primary outcome data were parent engagement, missing data from children centres were considered to indicate a lack of engagement; thus, imputation was not appropriate. While we met our recruitment target, this lack of data inevitably reduced our statistical power and resulted in wide variability. It is also possible, that the disruptions influenced the ability and priority of centres to collect and share data. It is possible that more parents engaged in the HENRY programme than were recorded. Further, HENRY engagement initiatives occurring in control areas may have 'diluted' the intervention effects by which parents attending centres in the control condition received some of the recommended strategies which may have influenced enrolment or completion. Our process evaluation highlighted the difficulties in maintaining a control condition in a pragmatic trial where centres in both trial arms sought to enhance engagement to HENRY to maximise value for money. Inviting centres that were HENRY naïve to participate in the trial may have minimised the sharing of knowledge and ideas on ways to promote engagement prior to the study.

\section{Abbreviations}

cRCT Cluster Randomised Controlled Trial

CTRU Clinical Trials Research Unit

OFTEN Optimising Family EngagemenT in HENRY

ICC Intra-cluster correlation coefficient

\section{Declarations}

\section{Ethics approval and consent to participate}

The trial study was approved by the School of Medicine Research Ethics Committee at the University of Leeds (MREC15-017).

\section{Consent for publication}

Not applicable

\section{Availability of data and materials}

The data that support the findings of this study are available from HENRY central office but restrictions apply to the availability of these data, which were used under license for the current study, and so are not publicly available. Data are however available from the authors upon reasonable request and with permission of HENRY central office.

\section{Competing interests}


$\mathrm{KR}$ is the chief executive of HENRY, which may receive increased publicity and consequent commissioning as a result of this research. KR was blinded to treatment allocation and was excluded from steering committee meetings. Involvement of KR was essential for the development of the optimisation intervention under investigation (ensuring feasible approaches were recommended and agreeing on related incurred costs). At the time of the study, HR was supported by the NIHR Collaboration for Leadership in Applied Health Research and Care (CLAHRC) North Thames at Barts Health NHS Trust. The other authors declare that they have no competing interests.

\section{Authors' contributions}

$M B$ and JS conceived the study. MB secured funding with support from JN, AJF, JS, JB, RF and HR. WB, $\mathrm{KR}, \mathrm{JB}$ and $\mathrm{MB}$ participated in the design of the intervention and the development of the recruitment strategy. All authors contributed to the design of the trial. BC, AJF, JB, MB, MC and SH advised on the statistical design and sample size calculation and also developed the recruitment strategy. ST led the economic evaluation design. All authors contributed to the writing of the manuscript and prepared a draft manuscript. All authors read and approved the final manuscript.

\section{Acknowledgements}

We acknowledge our parent advisory team for their support in developing the intervention and ongoing advice in study design and recruitment (Amal Najlat, Chloe Anderson, Kelly Milner, Claire Donkin, Sarah Young, Terri Francis and Rachael Baptista). We thank members of the trials steering committee (TSC), including Professor Peymane Adab (TSC Chair, University of Birmingham), Professor Alicia O'Cathain (mixed methods expert, University of Sheffield), Professor Kelvin Jordan (statistical expertise, Keele University), Dr Thomas Willis (behaviour change expertise, University of Leeds) and Amal Najlat (parent representative). We are also grateful to the children's centres that permitted observations which support the intervention development (anonymous). We acknowledge the optimisation intervention development team for their significant contributions (Professor Pinki Sahota, Dr Maureen Twiddy, Jackie Moores and Chloe Anderson). We thank the HENRY team for their support in developing and delivering the intervention, providing data and liaising with centres (Rebecca Nourse, Sian Livsey and Kim Roberts)

\section{Funding}

The trial was funded by the NIHR Trainees Coordinating Programme awarded to the chief investigator (MB) (CDF-2014-07-052). The views expressed are those of the authors and not necessarily those of the $\mathrm{NHS}$, the NIHR or the Department of Health.

\section{References}

1. Leblanc ES, O'Connor E, Whitlock EP, Patnode CD, Kapka T. Effectiveness of primary care-relevant treatments for obesity in adults: a systematic evidence review for the U.S. Preventive Services Task Force. Annals of internal medicine. 2011;155(7):434-47. 
2. Loveman E, Frampton GK, Shepherd J, Picot J, Cooper K, Bryant J, et al. The clinical effectiveness and cost-effectiveness of long-term weight management schemes for adults: a systematic review. Health technology assessment (Winchester, England). 2011;15(2):1-182.

3. Summerbell CD, Ashton V, Campbell KJ, Edmunds L, Kelly S, Waters E. Interventions for treating obesity in children. The Cochrane database of systematic reviews. 2003(3):CD001872.

4. Summerbell CD, Waters E, Edmunds LD, Kelly S, Brown T, Campbell KJ. Interventions for preventing obesity in children. The Cochrane database of systematic reviews. 2005(3):CD001871.

5. Williams NA, Coday M, Somes G, Tylavsky FA, Richey PA, Hare M. Risk factors for poor attendance in a family-based pediatric obesity intervention program for young children. J Dev Behav Pediatr. 2010;31(9):705-12.

6. Clarke AT, Marshall SA, Mautone JA, Soffer SL, Jones HA, Costigan TE, et al. Parent attendance and homework adherence predict response to a family-school intervention for children with ADHD. Journal of clinical child and adolescent psychology : the official journal for the Society of Clinical Child and Adolescent Psychology, American Psychological Association, Division 53. 2015;44(1):5867.

7. Hillier F, Pedley C, Summerbell C. Evidence base for primary prevention of obesity in children and adolescents. Bundesgesundheitsblatt, Gesundheitsforschung, Gesundheitsschutz. 2011;54(3):25964.

8. Bumbarger B, Perkins D. After randomised trials: issues related to dissemination of evidence-based interventions. Journal of Children's Services. 2008;3(2):55-64.

9. Mian ND. Little children with big worries: addressing the needs of young, anxious children and the problem of parent engagement. Clinical child and family psychology review. 2014;17(1):85-96.

10. Chiolero A, Paradis G, Paccaud F. The pseudo-high-risk prevention strategy. International Journal of Epidemiology. 2015;44(5):1469-73.

11. Reyno SM, McGrath PJ. Predictors of parent training efficacy for child externalizing behavior problems--a meta-analytic review. Journal of child psychology and psychiatry, and allied disciplines. 2006;47(1):99-111.

12. Mah JW, Johnston C. Parental social cognitions: considerations in the acceptability of and engagement in behavioral parent training. Clinical child and family psychology review. 2008;11(4):218-36.

13. Arai L, Stapley S, Roberts H. 'Did not attends' in children 0-10: a scoping review. Child: care, health and development. 2014;40(6):797-805.

14. Public Health England. NCMP and Child Obesity Profile. 2020.

15. Lindsay G, Cullen M. A short report to inform local commissioning processes. In: Education Df, editor. 2012.

16. Willis TA, George J, Hunt C, Roberts KP, Evans CE, Brown RE, et al. Combating child obesity: impact of HENRY on parenting and family lifestyle. Pediatric obesity. 2014;9(5):339-50. 
17. Rudolf MC, Hunt C, George J, Hajibagheri K, Blair M. HENRY: development, pilot and long-term evaluation of a programme to help practitioners work more effectively with parents of babies and pre-school children to prevent childhood obesity. Child: care, health and development. 2010;36(6):850-7.

18. Willis TA, Potrata B, Hunt C, Rudolf MCJ. Training community practitioners to work more effectively with parents to prevent childhood obesity: the impact of HENRY upon Children's Centres and their staff. Journal of Human Nutrition and Dietetics. 2012;25(5):460-8.

19. Hunt C, Rudolf, M. Tackling childhood obesity with HENRY: a handbook for community practitioners. . London: Unite/Community Practitioners' and Health Visitors' Association 2008.

20. Burton W, Twiddy M, Sahota P, Brown J, Bryant M. Participant engagement with a UK communitybased preschool childhood obesity prevention programme: a focused ethnography study. Bmc Public Health. 2019;19(1).

21. Burton W, Sahota P, Twiddy M, Brown J, Bryant M. The development of a multilevel intervention to optimise participant engagement with an obesity prevention programme delivered in children's centres. Prevention Science. 2021; In press.

22. Burton W, Twiddy M, Sahota P, Brown J, Bryant M. Participant engagement with a UK communitybased preschool childhood obesity prevention programme: a focused ethnography study. BMC Public Health. 2019;19(1):1074.

23. Bryant M, Burton W, Cundill B, Farrin AJ, Nixon J, Stevens J, et al. Effectiveness of an implementation optimisation intervention aimed at increasing parent engagement in HENRY, a childhood obesity prevention programme - the Optimising Family Engagement in HENRY (OFTEN) trial: study protocol for a randomised controlled trial. Trials. 2017;18(1):40.

24. Carter BR, Hood K. Balance algorithm for cluster randomized trials. BMC Med Res Methodol. 2008;8:65.

25. Department for communities and local government. The English Index of Multiple Deprivation (IMD) 2015 - Guidance. 2015.

26. Blake-Lamb TL, Locks LM, Perkins ME, Woo Baidal JA, Cheng ER, Taveras EM. Interventions for Childhood Obesity in the First 1,000 Days A Systematic Review. American Journal of Preventive Medicine.

27. Redsell SA, Edmonds B, Swift JA, Siriwardena AN, Weng S, Nathan D, et al. Systematic review of randomised controlled trials of interventions that aim to reduce the risk, either directly or indirectly, of overweight and obesity in infancy and early childhood. Maternal \& child nutrition. 2016;12(1):24-38.

28. Michie S, van Stralen MM, West R. The behaviour change wheel: A new method for characterising and designing behaviour change interventions. Implementation Science : IS. 2011;6:42-.

29. Hoffmann TC, Glasziou PP, Boutron I, Milne R, Perera R, Moher D, et al. Better reporting of interventions: template for intervention description and replication (TIDieR) checklist and guide. BMJ. 2014;348:g1687. 
30. Willis TA, Roberts KPJ, Berry TM, Bryant M, Rudolf MCJ. The impact of HENRY on parenting and family lifestyle: A national service evaluation of a preschool obesity prevention programme. Public Health. 2016;136:101-8.

31. Dumka LE, Stoerzinger HD, Jackson KM, Roosa MW. Examination of the Cross-Cultural and CrossLanguage Equivalence of the Parenting Self-Agency Measure. Family Relations. 1996;45(2):216-22.

32. Golan M, Weizman A. Reliability and validity of the Family Eating and Activity Habits Questionnaire. Euro J Clin Nutr. 1998;52(10):771-7.

33. Moore G, Audrey S, Barker M, Bond L, Bonell C, Hardeman W, et al. Process evaluation of complex interventions: Medical Research Council guidance. BMJ. 2015;350(h1258).

34. Steckler A, Linnan L. Process Evaluation for Public Health Interventions and Research: Wiley; 2014.

35. Weiss CH. Theory-based evaluation: Past, present, and future. 1997;1997(76):41-55.

36. Hayes RJ, Moulton LH. Cluster Randomised Trials. Hall/CRC C, editor2009.

37. Fairclough DF. Design and analysis of quality of life studies in clinical trials. London New York: Chapman \& Hall/CRC; 2010.

38. Heritier S. Design and Analysis of Quality of Life Studies in Clinical Trials, 2nd edn. By Diane L. Fairclough. Boca Raton, Florida: Chapman \& Hall/CRC. 2010. 424 pages. $£ 57.99$ (hardback). ISBN 978-1-4200-6117-8. 2013;55(1):56-7.

39. Soekhai V, de Bekker-Grob EW, Ellis AR, Vass CM. Discrete Choice Experiments in Health Economics: Past, Present and Future. PharmacoEconomics. 2019;37(2):201-26.

40. Webb EJD, Stamp E, Collinson M, Farrin AJ, Stevens J, Burton W, et al. Measuring commissioners' willingness-to-pay for community based childhood obesity prevention programmes using a discrete choice experiment. BMC Public Health. 2020;20(1):1535.

41. May M. Government spending on 'lifeline' children's Sure Start centres slashed by nearly $£ 157 \mathrm{~m}$ in four years. The Independent. 201922 March.

42. Action for Children. Society, Losing in the long run. Trends in early intervention funding. 2016.

43. Deave T, Hawkins A, Kumar A, Hayes M, Cooper N, Watson M, et al. Evaluating implementation of a fire-prevention injury prevention briefing in children's centres: Cluster randomised controlled trial. PLOS ONE. 2017;12(3):e0172584.

44. Beckett $K$, Goodenough $T$, Deave $T$, Jaeckle S, McDaid L, Benford $P$, et al. Implementing an Injury Prevention Briefing to aid delivery of key fire safety messages in UK children's centres: qualitative study nested within a multi-centre randomised controlled trial. BMC Public Health. 2014;14(1):1256.

45. Hawe P, Shiell A, Riley T. Complex interventions: how "out of control" can a randomised controlled trial be? BMJ. 2004;328(7455):1561-3.

46. Action for Children, National Children's Bureau, Society TCs. Losing in the long run. Trends in early intervention funding. . Action for Children; 2016.

47. Mytton J, Ingram J, Manns S, Thomas J. Facilitators and barriers to engagement in parenting programs: a qualitative systematic review. Health education \& behavior : the official publication of 
the Society for Public Health Education. 2014;41(2):127-37.

48. Butler J, Gregg L, Calam R, Wittkowski A. Parents' Perceptions and Experiences of Parenting Programmes: A Systematic Review and Metasynthesis of the Qualitative Literature. Clinical child and family psychology review. 2020;23(2):176-204.

49. Schell SF, Luke DA, Schooley MW, Elliott MB, Herbers SH, Mueller NB, et al. Public health program capacity for sustainability: a new framework. Implementation Science. 2013;8(1):15.

50. Stevens J, Taber DR, Murray DM, Ward DS. Advances and controversies in the design of obesity prevention trials. Obesity (Silver Spring). 2007;15(9):2163-70.

51. Gilbert H, Sutton S, Morris R, Petersen I, Galton S, Wu Q, et al. Effectiveness of personal tailored risk information and taster sessions to increase the uptake of smoking cessation services (Start2quit) : a randomised controlled trial. Lancet. 2017 389(10071):823-33.

52. Blaine RE, Franckle RL, Ganter C, Falbe J, Giles C, Criss S, et al. Using School Staff Members to Implement a Childhood Obesity Prevention Intervention in Low-Income School Districts: the Massachusetts Childhood Obesity Research Demonstration (MA-CORD Project), 2012-2014. Preventing chronic disease. 2017;14:E03.

53. Davis CC, Claudius M, Palinkas LA, Wong JB, Leslie LK. Putting families in the center: family perspectives on decision making and ADHD and implications for ADHD care. Journal of attention disorders. 2012;16(8):675-84.

54. Ramanadhan S WJ, Gortmaker SL, Emmons KM, K. V. Informal training in staff networks to support dissemination of health promotion programs. . American Journal of Health Promotion. 2010;12(1):12-8.

55. Tinati T, Lawrence W, Ntani G, Black C, Cradock S, Jarman M, et al. Implementation of new Healthy Conversation Skills to support lifestyle changes - what helps and what hinders? Experiences of Sure Start Children's Centre staff. Health Soc Care Community. 2012;20(4):430-7.

56. Goodenough T, Kay B, Deave T, Towner E, Stewart J, Ablewhite J, et al. Barriers and facilitators to delivering injury prevention interventions in English children's centres. International Journal of Health Promotion and Education. 2016;54(2):60-71.

57. Bloomquist ML, August GJ, Lee SS, Lee CY, Realmuto GM, Klimes-Dougan B. Going-to-scale with the Early Risers conduct problems prevention program: use of a comprehensive implementation support (CIS) system to optimize fidelity, participation and child outcomes. Evaluation and program planning. 2013;38:19-27.

58. Friars P, Mellor D. Drop-out from parenting training programmes: a retrospective study. J Child Adolesc Ment Health. 2009;21(1):29-38.

59. Gross D, Julion W, Fogg L. What Motivates Participation and Dropout Among Low-Income Urban Families of Color in a Prevention Intervention?*. Family Relations. 2001;50(3):246-54.

60. Beatty D, King A. Supporting fathers who have a child with a disability. Groupwork. 2012;18(3):69-87.

61. Owens J, Richerson L, Murphy C, Jageleweski A, Rossi L. The Parent Perspective: Informing the Cultural Sensitivity of Parenting Programs in Rural Communities. Child \& Youth Care Forum. 
2007;36:179-94.

62. Wheatley SL, Brugha TS, Shapiro DA. Exploring and enhancing engagement to the psychosocial intervention 'Preparing for Parenthood'. Archives of Women's Mental Health. 2003;6(4):275-85.

63. Pearson C, Thurston M. Understanding Mothers' Engagement with Antenatal Parent Education Services: A Critical Analysis of a local Sure Start Service. Children \& Society. 2006;20(5):348-59.

\section{Figures}




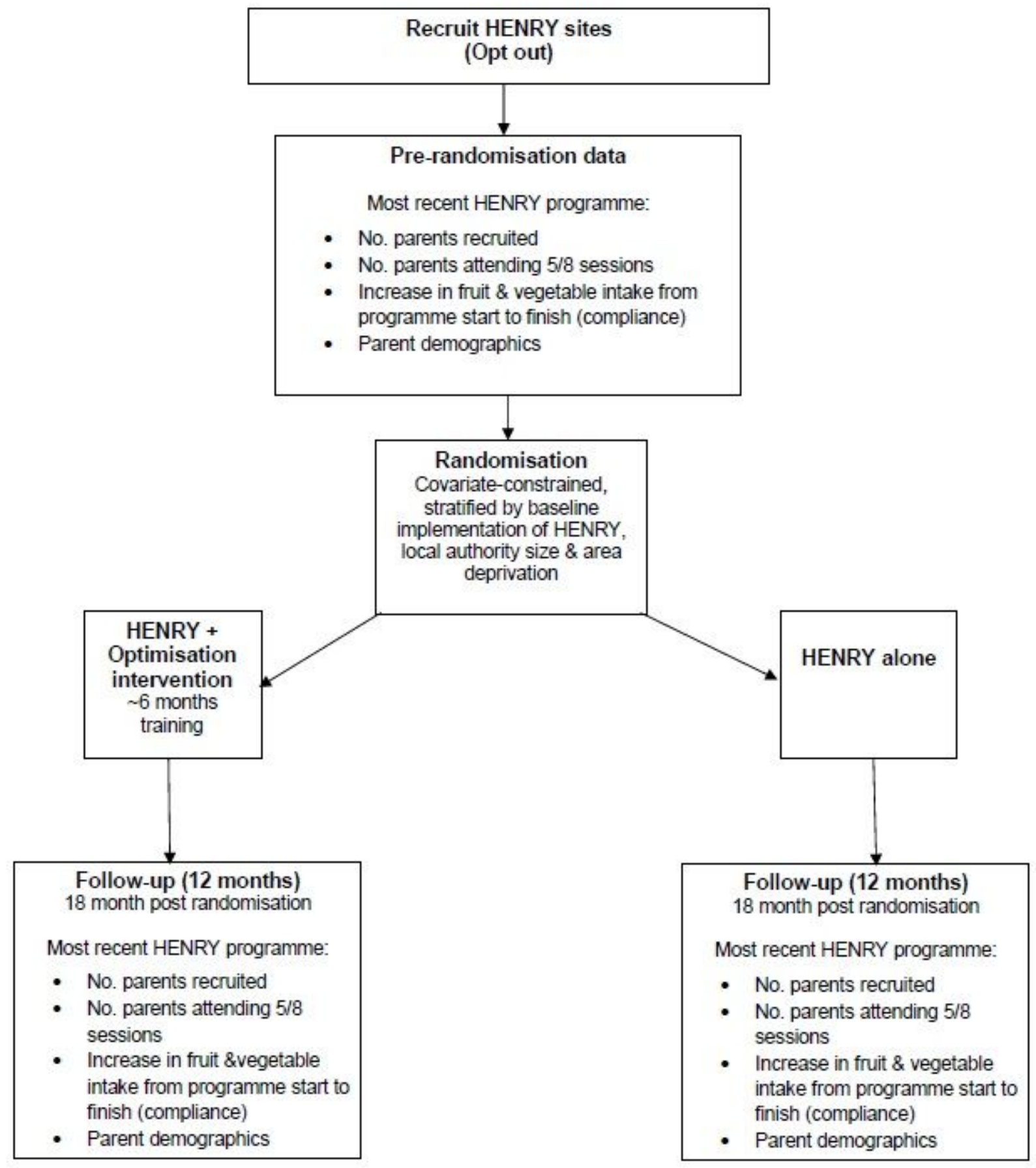

Pre-randomisation (baseline) and follow-up data for primary and secondary outcomes - all from routine process data collected by children's centres and managed by the central HENRY team.

ITT analysis conducted

\section{Figure 1}

Study design 


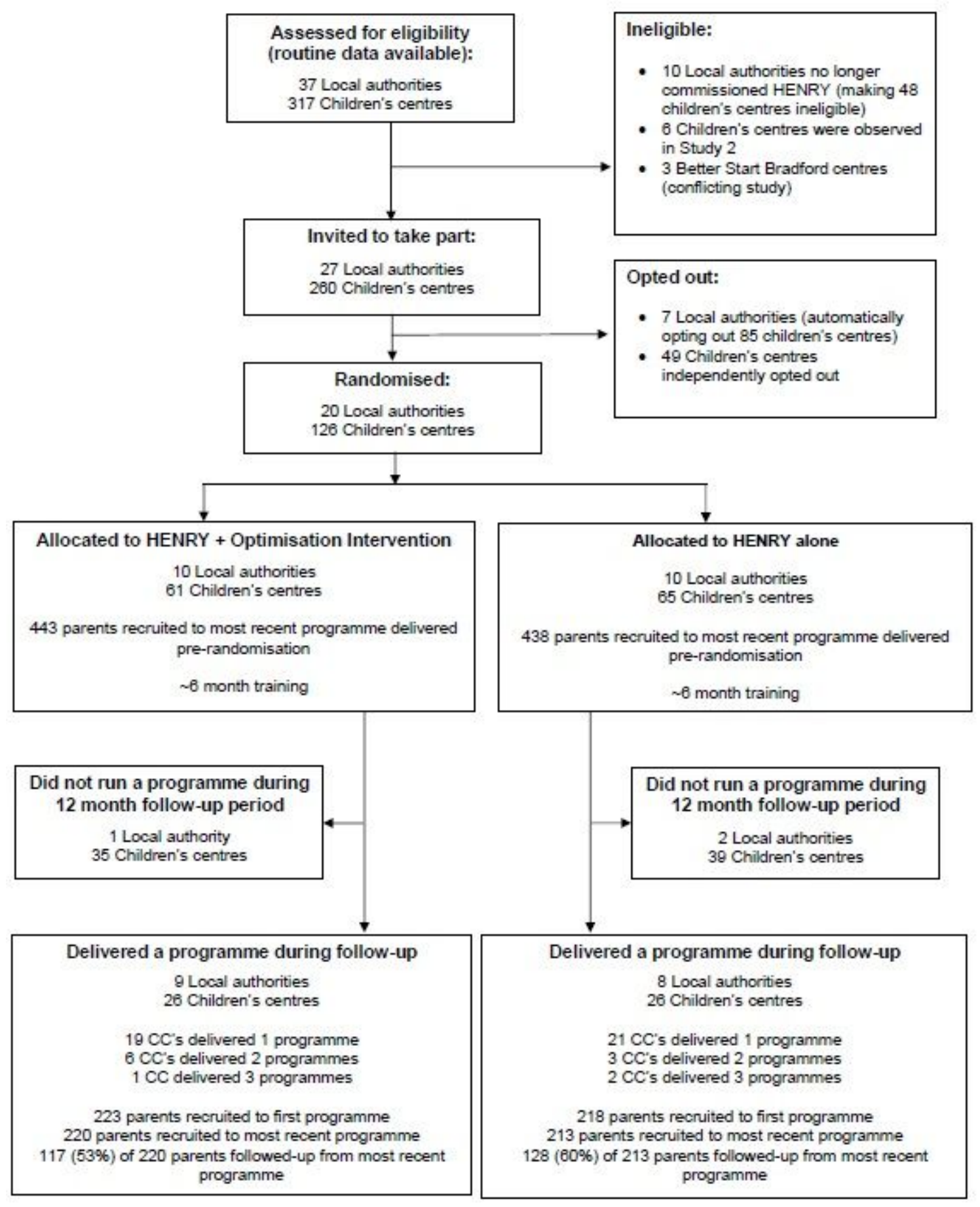

Note: No Local authorities or Children's centres withdrew. There were no eligibility violations.

Figure 2

CONSORT flow diagram

\section{Supplementary Files}

This is a list of supplementary files associated with this preprint. Click to download. 